\title{
Characterization of Xylella fastidiosa popP Gene Required for Pathogenicity
}

\author{
Xiangyang Shi ${ }^{1,2 *}$ and Hong Lin ${ }^{2 *}$ \\ ${ }^{1}$ Department of Plant Science, University of California, Davis, CA 95616, USA \\ ${ }^{2}$ Crop Diseases, Pests \& Genetics Research Unit, San Joaquin Valley Agricultural Sciences Center, USDA-ARS, Parlier, CA 93648, USA
}

\begin{abstract}
Xylella fastidiosa $(X f)$ possess a two component regulatory system (TCS) PopP-PopQ which differentially regulates genes in response to environmental stimuli. To elucidate the role of popP in the pathogenicity of $X$. fastidiosa causing Pierce's disease (PD) of grapevine, a site-directed deletion method and chromosome-based genetic complementation strategy were employed to create popP deletion mutant $X f \Delta p o p P$ and its complementary strain $X f \Delta p o p P-C$. In vitro studies showed that while all strains had similar growth curves, $X f \Delta p o p P$ showed significant reduction in cell-cell aggregation and cell-matrix adherence. Biofilm production of $X f \Delta p o p P$ was about $42 \%$ less than that of wild type $X$. fastidiosa and $X f \Delta p o p P-C$. No symptoms were observed in grapevines inoculated with $X f \Delta p o p P$, whereas grapevines inoculated with wild type $X$. fastidiosa and $X f \Delta p o p P-C$ showed typical PD symptoms. Several biofilm-related genes and genes involving protein secretary systems were down regulated in $X f \Delta p o p P$ in compared with wild type $X$. fastidiosa and $X f \Delta p o p P-C$. These in vitro and in planta assay results provide strong evidence that the role of PopP is required for pathogenicity of $X$. fastidiosa on grapevine.
\end{abstract}

Keywords: Xylella fastidiosa; Pierce's disease; Pathogenicity; Two component regulatory system (TCS); PopP

\section{Introduction}

Xylella fastidiosa $(\mathrm{X} f)$ is a xylem-limited gram-negative plant pathogenic bacterium, which causes diseases in many plants, including Pierce's disease (PD) in grapevine [1]. In diseased plants, X. fastidiosa cells are embedded in the plant vessel matrix in clumps (biofilm) and result in the blockage of the water flow within the xylem vessels. The formation of biofilms allows the pathogenic bacteria to adapt in low nutrition and sub-optimal osmolarity conditions, potentially protecting them from a hostile environment [2]. The bacteria to sense changes in the environment and to differentially regulate genes in response to environmental stimuli employ the regulatory systems. These regulatory circuits are generally involved in the two-component systems (TCS) in pathogenic bacteria [3]. One of the TCS used by bacteria to sense the environment is TCS PhoP-PhoQ, which senses specific nutrients and regulates responses in the bacteria [3].

The PhoP-PhoQ is a well-studied and highly conserved TCS responsible for the regulation of genes involved in the adaptation to new environments. PhoQ is a transmembrane histidine kinase protein with a long C-terminal tail residing in the cytoplasm, involved in sensing for extracellular signal [3]. Upon activation via environmental stimuli, PhoQ phosphorylates the corresponding response regulator PhoP, which regulates gene expression in response to environment stress [3]. In phytopathogenic Xanthomonas oryzae pv. oryzae, TCS PhoP-PhoQ was recently shown to be a requirement for the induction of density-dependent gene expression, including genes related with biofilm formation [4-7]. PhoP-PhoQ controls virulence functions in the plant pathogen Erwinia carotovora and E. chrysanthemi [8-11]. A cell wall degrading enzyme endopolygalacturonase (designated PehA) secreted by Erwinia is transcriptionally regulated by the PhoP-PhoQ homologue PehR-PehS, and the pehR or pehS deficient of Erwinia are attenuated for virulence in tobacco seedlings [8].

Evidently, the PhoP-PhoQ system is required for virulence in several animal pathogens. Salmonella species are facultative intracellular pathogens that can infect a wide variety of animals causing different diseases [12]. A phoP mutant of the etiologic agent of bubonic plagues Yersinia pestis [13,14], reduced the abilities to survival within macrophages, and increased sensitivity to low $\mathrm{pH}$, oxidative stress, and high osmolarity [15]. A phoP deficient of Shigella is hypersensitive to killing by neutrophils [16]. The phoP or phoQ deletion mutant of Salmonella is highly attenuated for virulence [17-19]. More than forty genes regulated by phosphorylated PhoP have been shown to play important roles in the survival and the pathogenesis of Salmonella within macrophages $[19,20]$. While Salmonella, Shigella, and Yersinia cause different diseases in animal, inactivation of the $p h o P$ gene results in the defective for survival and virulence in their hosts.

The homologue of PopP-PopQ was identified in the X. fastidiosa genome [21]. To elucidate the role of TCS regulator popP in $X$. fastidiosa, here, we characterize $X$. fastidiosa popP gene by comparing the phenotypes of a deletion mutant $X f \Delta p o p P$, complementary strain $X f \triangle p o p P-C$ and its wild-type $X$. fastidiosa in vitro and in planta studies. These results confirm the role of $p o p P$ pathogenicity in $X$. fastidiosa on grapevine.

*Corresponding author: Xiangyang Shi, Department of Plant Science, University of California, Davis, CA 95616, USA, Tel: 5595962911; E-mail: shixy2100@yahoo. com

Hong Lin, Crop Diseases, Pests \& Genetics Research Unit, San Joaquin Valley Agricultural Sciences Center, USDA-ARS, Parlier, CA 93648, USA, Tel: 5595962933; E-mail: hong.lin@ars.usda.gov

Received August 14, 2015; Accepted August 21, 2015; Published August 25 2015

Citation: Shi X, Lin H (2015) Characterization of Xylella fastidiosa popP Gene Required for Pathogenicity. J Plant Pathol Microb 6: 295. doi:10.4172/21577471.1000295

Copyright: (c) 2015 Shi X, et al. This is an open-access article distributed under the terms of the Creative Commons Attribution License, which permits unrestricted use, distribution, and reproduction in any medium, provided the original author and source are credited. 


\section{Materials and Methods}

\section{Construction of $X f \Delta p o p P$ mutant and complementation strain $X f \Delta p o p P-C$}

A crossover PCR-based strategy for a site-directed deletion was used to construct an $X f \Delta p o p P$ mutant of $X$. fastidiosa [22]. The replacement of the $p o p P$ ORF with a Gentamicin cassette in the genome of $X f \Delta p o p P$ was confirmed by sequencing. The complementation strain $X f \Delta p o p P-\mathrm{C}$ was generated by the chromosome-based genetic complementation strategy [23]. The location of popP gene incorporating into the chromosome of $X f \Delta p o p P-C$ was confirmed by PCR. All amplified DNA fragments were confirmed by resequencing. The bacterial strains, plasmids, and primers used in this work are listed in Tables 1 and 2.

\section{The detection of expression of popP}

A modified hot-phenol RNA preparation procedure was used to extract the total RNA from wild type $X$. fastidiosa, $X f \Delta p o p P$, and $X f \Delta p o p P-C$ [24]. Bacterial cultures were incubated in $50 \mathrm{ml}$ of PD2 broth at $28^{\circ} \mathrm{C}$ for 5 days under constant agitation at $200 \mathrm{rpm}$. After the hot-phenol extraction, RNA was dissolved in RNase-free distilled

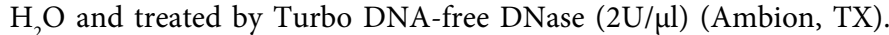
The quality of isolated RNAs was determined by denaturing RNA formaldehyde gel electrophoresis [25]. The expression of popP was analyzed by reverse transcription polymerase chain reaction (RT-PCR) with primers popPmRNAXf-F/R (Table 2), using the AccessQuick RTPCR System according to the manufacturer's instructions (Promega, $\mathrm{WI}$ ). The expression of DNA polymerase III related gene dnaQ served as a positive control (Table 1). RT-PCR was conducted in three independent experiments.

\section{Pathogenicity assays}

Wild type $X$. fastidiosa, $X f \Delta p o p P$, and $X f \Delta p o p P-C$ were grown on PD2 agar medium for 5 days at $28^{\circ} \mathrm{C}$, suspended in sterile deionized water, and adjusted to an $\mathrm{OD}_{600}$ of 0.10 . A 20 - $\mu$ l of cell suspension was used to inoculate five plants of Cabernet Sauvignon by a needle inoculation procedure described previously [26]. A water inoculation served as a negative control. The inoculated grapevines were kept on benches in a greenhouse at 24 to $32^{\circ} \mathrm{C}$ with $18 \mathrm{hr}$ of exposure supplemented with High-Pressure Sodium lamp (20 watts per sq. ft.) [27]. Pierce's disease symptoms were observed two months post inoculation. The symptoms were rated on a scale from 0 to 5 as described previously [28] with 0 representing healthy grapevines without any scorched leaves (water control) and 5 representing plants with severely scorching symptoms. The final disease index was an average from 5 independent replications in each $X$. fastidiosa strain. The pathogenicity assays on grapevine were conducted in three independent inoculation experiments in greenhouse from May 2012 to July 2014.

\section{Bacterial titer assessment}

To confirm and detect the bacterial population in inoculated grapevines, 10 -week post inoculation petioles $(2$ to $3 \mathrm{~cm}$ ) from each grapevine inoculated with wild type X. fastidiosa, Xf $\triangle p o p P$, and $X f \Delta p o p P-C$ were harvested at $50 \mathrm{~cm}$ above the inoculation points. Total DNAs (plant and bacteria) were prepared from the petioles according to standard DNA extraction procedure [29]. The DNA samples were amplified by PCR using specific Rst31/33 primers [30] to confirm $X$. fastidiosa in the samples. The concentrations of DNA extracted from the leaf petiole of healthy and inoculated grapevine were quantified by PicoGreen Dye using DNA Auant Kit (Invitrogen, CA), and diluted to $5 \mathrm{ng} / \mu \mathrm{l}$. The copy numbers of $X$. fastidiosa genomic DNA in the samples were estimated using quantitative PCR (qPCR) according to the method described earlier [29]. The assessment of bacterial titer was evaluated from three independent experiments.

\section{Phenotypic analyses}

In vitro growth curves of wild type $X$. fastidiosa, $X f \Delta p o p P$, and $X f \Delta p o p P-\mathrm{C}$ were determined after 3 to 21 days of growth at $28^{\circ} \mathrm{C}$ as previously described [22]. Cell concentration was determined by measuring turbidity at $\mathrm{OD}_{600}$. Cell aggregations were analyzed as described previously [31,32]. Due to the aggregation of the cells in broth, cells of all tested strains cultured in PD2 broth were dispersed by repeated pipetting or vortexing, and processed to measure the turbidity of bacterial cells at the $\mathrm{OD}_{540 \mathrm{~nm}}$ according to the previously described methods [31,32]. Biofilm formation analyses were done by culturing all tested stains in 96-well plates as described previously [32]. The data were averaged from three replications.

\begin{tabular}{|c|c|c|}
\hline Strain or plasmid & Characteristic(s) & Source or reference \\
\hline \multicolumn{3}{|l|}{ Strains } \\
\hline Escherichia coli DH5 & 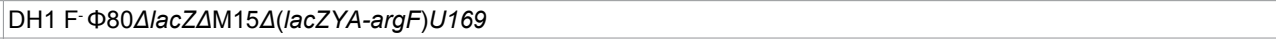 & Promega \\
\hline \multicolumn{3}{|l|}{$X$. fastidiosa $(X f)$} \\
\hline Temecula1 & $X$. fastidiosa wild type & \\
\hline$X f \Delta p o p P$ & Gentamicin $(\mathrm{Gm})$ cassette replacing entire popP ORF $(\triangle p o p P:: \mathrm{Gm})$ of $X$. fastidiosa wild type & This work \\
\hline$X f \Delta p o p P-C$ & 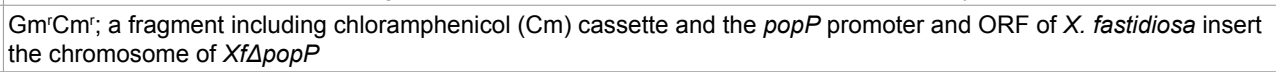 & This work \\
\hline \multicolumn{3}{|l|}{ Plasmids } \\
\hline pGEM-T Easy & $A p^{r} ;$ cloning vector & Promega \\
\hline pBBR1MCS-5 & $\mathrm{Gm}^{\mathrm{r}}$; broad-range plasmid & Kovach et al., [62] \\
\hline pGEM-T-GM & $\mathrm{Ap}^{r} \mathrm{Gm}^{\mathrm{r}} ; \mathrm{Gm}$ cassette from pBBR1MCS-5 cloned into pGEM-T & This work \\
\hline pUC129 & $\mathrm{Ap}^{\mathrm{r}}$; cloning vector & New England Biolabs \\
\hline pUC1679 & $\mathrm{Ap}^{r} ;$ mutagenized PCR fragment of the flanking regions of popP ORF of $X$. fastidiosa cloned into pUC129 & This work \\
\hline pUC16791 & Apr $\mathrm{Gm}^{r} ; \mathrm{Gm}$ cassette from pGEM-T-GM cloned into the Ascl site of pUC1679 & This work \\
\hline pBBR1MCS & $\mathrm{Cm}^{\mathrm{r}}$; broad-range plasmid & Kovach et al., [62] \\
\hline pUC129Cm & $\mathrm{Cm}^{\mathrm{r}} ; \mathrm{Cm}$ cassette from pBBR1MCS-3 cloned into pUC129 & This work \\
\hline $\mathrm{pUCpop} P_{\mathrm{Xf}-\mathrm{Exp}}$ & $\mathrm{Ap}^{r} \mathrm{Cm}^{r}$; a fragment including the popP promoter and ORF of $X$. fastidiosa cloned into pUC129Cm & This work \\
\hline
\end{tabular}

Table 1: Bacterial strains and plasmids used in this study. 


\begin{tabular}{|c|c|c|}
\hline popPA & 5'- AGTAATAGTACGATGCCAGCA-3' & This work \\
\hline popPB & 5'- CGGCGCGCCGGATCTGCTGTGCACCATGTT-3' & This work \\
\hline popPC & 5'- CGGCGCGCCGTATCTAAAGGTTATCGGCAC-3' & This work \\
\hline popPD & 5'- ATTAGAGCTTCTCCTCCAAT-3' & This work \\
\hline popPORF For & 5'- GCGTCAAGCGCATAACCAGC-3' & This work \\
\hline popPORF Rev & 5'- CTCTTCACGCATGGACGTTG-3' & This work \\
\hline $\mathrm{Gm}-\mathrm{F}$ & 5'-GAATTGACATAAGCCTGTTC-3' & This work \\
\hline Gm-R & 5'-CGTTGTGACAATTTACCGAA-3' & This work \\
\hline popPXFExpFor & 5'- ACATGGTGCACAGCAGATCT-3' & This work \\
\hline popPXFExpRev & 5'- ATACGATAGATTTTGTGGCT-3' & This work \\
\hline popPmRNAXf-F & 5'-TTAATTTTCGTTGCGGGCAA-3' & This work \\
\hline popPmRNAXf-R & 5'-TGCCGTTCGATGTTGGTATT-3' & This work \\
\hline $\mathrm{CmF}$ & 5'-GGATGCATATGATCAGATCTT-3' & This work \\
\hline $\mathrm{CmR}$ & 5'-TCACTTATTCAGGCGTAGCAC-3' & This work \\
\hline PD0702For & 5'-CACGCCCGTTATTAATCGAA-3' & This work \\
\hline PD0703Rev & 5'-TAACCTTGTCAGCGTAGATG-3' & This work \\
\hline Rst31 & 5'-GCGTTAATTTTCGAAGTGATTCGATTGC-3' & Minsavage et al., [30] \\
\hline Rst33 & 5'-CACCATTCGTATCCCGGTG-3' & Minsavage et al., [30] \\
\hline pUCFor & 5'-GTTTTCCCAGTCACGAC-3' & Promega \\
\hline pUCRev & 5'-CAGGAAACAGCTATGAC-3' & Promega \\
\hline M13For & 5'-CGCCAGGGTTTTCCCAGTCACGAC-3' & Promega \\
\hline M13Rev & 5'-TCACACAGGAAACAGCTATGAC-3' & Promega \\
\hline GacA-F & 5'-TGAGTGCCTTCTAAGTACCT-3' & This work \\
\hline GacA-R: & 5'-TGCGTAGCGCAGTATCTACT-3' & This work \\
\hline dnaQFor & 5'-TTACGCAACTTGGCCAAACG-3' & This work \\
\hline dnaQRev & 5'-TGGAATGGAGCAAGGGGAAC-3' & This work \\
\hline
\end{tabular}

Table 2: Primers used in this study.

\section{The differentially expressed genes between wild type, $X f \Delta p o p P$, and $X f \Delta p o p P-C$ in vitro}

Previously, studies showed that PhoP differentially regulated genes involving pathogenesis on the host [20]. Based on the genome sequences of $X$. fastidiosa 9a5c (a CVC strain) [21] and X. fastidiosa Temecula1 (a PD strain) [33], genes associated with putative roles in $X$. fastidiosa virulence, the metabolism of nucleic acids and proteins, and cellular transport and stress tolerance were selected for differential expression analysis (Table S1). Total RNA was extracted from wild type $X$. fastidiosa, $X f \Delta p o p P$, and $X f \Delta p o p P-C$ strains grown in $\mathrm{PD} 2$ at an initial $\mathrm{OD}_{600 \mathrm{~mm}}$ of 0.05 of in final volumes of $2 \mathrm{ml}$ in glass tubes, and were agitated at $200 \mathrm{rpm}$ at $28^{\circ} \mathrm{C}$ for 7 days [34,35]. Total RNA was extracted, DNase-treated, and purified to assure no contamination of DNA as described previously $[26,34,35]$. RT-PCR was conducted with primers specifically designed to amplify internal regions of the ORFs of the selected genes (S1). Ten microliters of amplified product was run on agarose gels and visualized under UV light. RT-PCR was conducted for three biological replicates from three independent experiments.

\section{Results}

\section{Physiological properties of $\mathrm{Xf} \Delta \mathrm{popP}$ in vitro}

Sequence analysis confirmed that gentamicin cassette physically replaced the entire popP ORF from start codon ATG to terminal codon TAA in the wild type $X$. fastidiosa genome. The expression of popP in $X f \triangle p o p P$ was not detectable with RT-PCR. Successfully complemented cells from chloramphenicol-resistance clones were confirmed by PCR. Sequence analysis further confirmed that popP gene (promoter and ORF) was incorporated into the site between PD0702 and PD0703 of chromosome of $X f \Delta p o p P$ as expected. Stable $X f \Delta p o p P$ and $X f \Delta p o p P-C$ colonies were obtained after five to eight streaks on PD2 agar medium supplemented with $10 \mu \mathrm{g} / \mathrm{ml} \mathrm{Gm}$ or $10 \mu \mathrm{g} / \mathrm{ml} \mathrm{Cm}$, respectively.
In vitro growth curves showed that $X f \Delta p o p P$ reached the exponential and stationary phase in a manner similar to wild type $X$. fastidiosa after twelve days in culture (data not shown). Whereas there was no obvious difference in colony morphology between wild type $X$. fastidios $a$ and $X f \Delta p o p P-C, X f \triangle p o p P$ had less sticky colonies when touched with a bacteriological loop (data not shown). The quantitative assessment of cell aggregation showed that $X f \Delta p o p P$ had about a $36 \%$ reduction in cell-to-cell aggregation comparing to that of wild type $X$. fastidiosa (Figure 1A). However, $X f \triangle p o p P-C$ had about a $19 \%$ reduction in cellto-cell aggregation in compared with the wild type $X$. fastidiosa. Biofilm formation by $X f \triangle p o p P$ was found to have about $42 \%$ less than that of wild type $X$. fastidios $a$ after ten days of static incubation determined by the crystal violet assay while complement strain $X f \triangle p o p P-C$ had about only $16.6 \%$ of reduction in biofilm formation in comparison with that of wild type $X$. fastidiosa (Figure 1B).

\section{Pathogenicity of $X f \Delta p o p P$ and $X f \Delta p o p P-C$ on grapevine}

In contrast to the grapevines inoculated with wild type $X$. fastidiosa and $X f \Delta p o p P-C$, grapevines infected by $X f \Delta p o p P$ showed no symptom 12 weeks post inoculation (Figures $2 \mathrm{~A}$ and $2 \mathrm{~B}$ ). Mock-inoculated control grapevines did not show any PD symptoms (Figures 2A and 2B). All diseased grapevines were detected positive for $X$. fastidiosa by PCR with $X$. fastidiosa specific primers Rst31/33 (data not shown), and grapevines in mock-inoculated group were detected negative. To further evaluate of the reduced virulence of $X f \Delta p o p P$, the bacterial titers in infected grapevines with wild type $X$ fastidiosa, $X f \Delta p o p P$, and $X f \triangle p o p P-C$ were estimated by $\mathrm{qPCR}$. The bacterial populations in grapevines infected with $X f \triangle p o p P$ showed about $66 \%$ less than those of grapevines inoculated with wild type $X$. fastidiosa (Figure 2C).

\section{popP regulated gene expression}

Most of selected genes were not differentially expressed among tested strains. However, TCS regulator popP, surface-exposed outer 
membrane gene $u s p A 1$, gum synthesized gene gumB, two-component system regulatory gene $\operatorname{alg} R$, type II secretory pathway protein-export membrane gene $\sec G$, and type $\mathrm{V}$ secretory pathway gene $m t t C$ were down regulated in $X f \triangle p o p P$ in comparison to wild type $X$. fastidiosa and $X f \Delta p o p P$-C (Figure 3). Both housekeeping genes, $\operatorname{tap} B$ (temperature acclimation) and $d n a Q$ (DNA polymerase III) were expressed almost equally in wild type $X$. fastidiosa, Xf $\Delta p o p P$, and $X f \Delta p o p P$-C.

\section{Discussion}

TCS PhoP-PhoQ system of Salmonella and Yersinia pestis is responsible for the virulence within animal host cells [13-15]. PhoPPhoQ of X. oryzae pv. oryzae (Xoo), E. carotovora, and E. chrysanthemi appears to be cell density-dependent in plant host [4-10]. In this study, while both wild type and popP mutant $X$. fastidiosa strains showed similar growth curves in vitro, grapevines infected with popP deletion strain have significantly decreased bacterial populations in comparison to the bacterial populations of grapevines inoculated with wild type. The severity of the disease has been known to be positively correlated with the titer of $X$. fastidiosa. Fritschi, et al. [36] investigated 18 grape genotypes in response to $X$. fastidiosa infection under greenhouse conditions and concluded that an inverse relationship was found between the level of PD resistance and bacterial populations in grapevines. No PD symptom was observed in the grapevines inoculated with popP deletion strain in compared with severe PD symptom developed by grapevines infected with wild type $X$. fastidiosa and complementary strain $X f \Delta p o p P-C$ consistently observed in repeated greenhouse inoculation tests. Similarity results were recently reported on the pathogenicity of $X f$ popP [37]. Our results demonstrate that pop $P$ is an important virulence factors and plays critical role for the survivals and the pathogenicity of $X$. fastidiosa.

Colonization, proliferation and biofilm formation of $X$. fastidios $a$ in water-conducting xylem vessels of host plants result in the blockage of water and nutrient in diseased plants $[38,39]$. In this study, the abilities of cell aggregation and biofilm formation of popP deficient strain were decreased while complementary strain $X f \Delta p o p P-\mathrm{C}$ significantly restored biofilm formation. popP is required for the regulation of density-dependent gene expression in $X$. fastidiosa, including genes responsible for biofilm formation. Biofilms are complex structures involving $X$. fastidiosa cells and an extracellular matrix. $X$. fastidiosa produces abundant multiple putative afimbrial adhesins, such as exopolysaccharide (EPS), lipopolysaccharide (LPS), and surface proteins, which contribute to the virulence of $X$. fastidiosa by attaching to the xylem wall in the plant and enhancing biofilm formation $[33,40$ 43]. Previously study showed that $X$. fastidiosa EPS was coded by a cluster of nine gum genes closely related to the xanthan gum operon of Xanthomonas campestris pv. campestris [44]. The disruption of gumB in X. fastidiosa did not affect exopolysaccharide production, the gumB mutant, however, does show a reduced capacity to form biofilm [44]. The two-component system regulatory algR in X. fastidiosa was previously reported to regulate the synthesis of the LPS, which could play a role in biofilm formation and cell attachment as well [2,45-47]. Surface-exposed outer membrane gene uspA1 was shown to be related to the virulence of $X$. fastidiosa [48]. Interestingly, in this study the expressions of $g u m B, u s p A 1$, and $\operatorname{algR}$ were repressed in popP mutant strain in contrast to the wild type $X$. fastidiosa, the mutation of $p o p P$ might reduce the production of LPS, resulting in the reduced capacity to form biofilm and cell-cell aggregation, both are important events of $X$. fastidiosa in successful colonization of the grapevine xylem. This might account for the significantly reduced disease severity of grapevines inoculated with $X f \Delta p o p P$.

The ability of $X$. fastidiosa to colonize grapevines and to incite disease development is also dependent upon the capacity of this bacterium to produce a diverse set of virulence factors $[33,49]$, which must be secreted to the bacterial cell surface or released them into the external environment. In X. fastidiosa, the important virulence determinants are delivered to the bacterial cell surface through type I, type II, and type $\mathrm{V}$ secretion systems $[21,33,50,51]$. It has been demonstrated that these actively secreted proteins are associated with bacterial pathogenicity or suppressing host defenses [52-54]. Matsumoto et al. [55] showed that XatA was one of six members of the AT- 1 autotransporter family
A

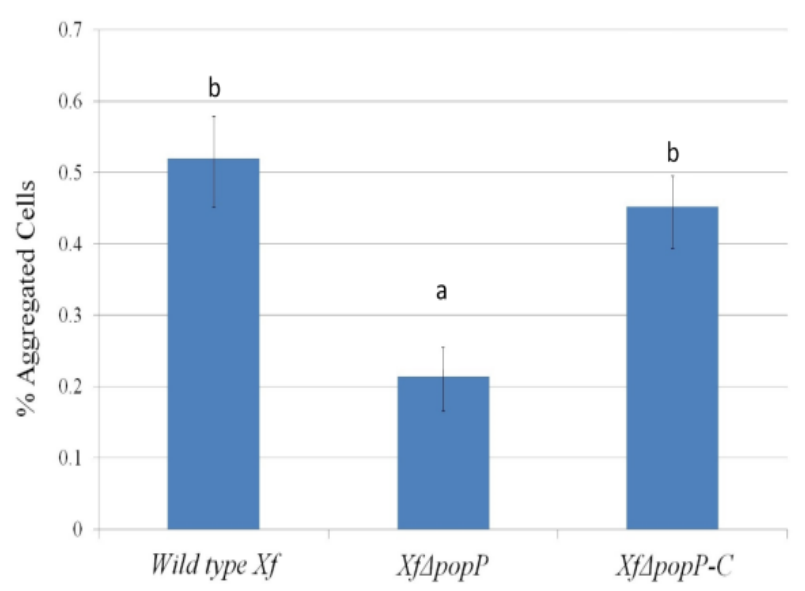

B

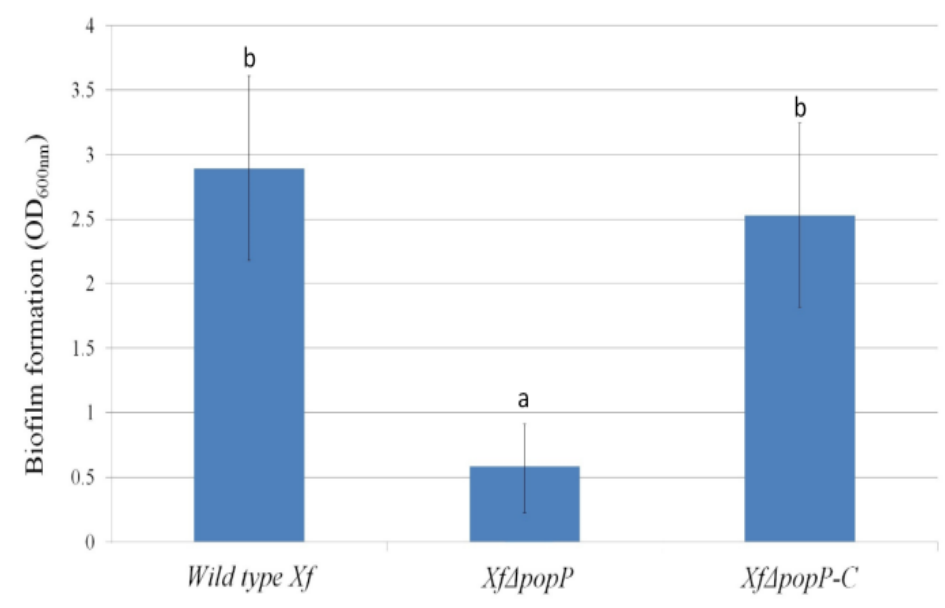

Figure 1: Quantitative assessment of cell-to-cell aggregation and biofilm formation of wild type $X$. fastidiosa, $X f \Delta p o p P$ and complement $X f \Delta p o p P$-C. A) The percentages of aggregated cells of $X$. fastidiosa strains in PD2 broth [63]. B) Quantitative assessment of biofilm formation of all tested $X$. fastidiosa strains. Averages and standard deviations of three independent experiments are shown for all assessment experiments. Error bars indicate standard deviation. Letters indicate groups assigned by significant difference test $(t$ test, $P<0.05)$ 
A

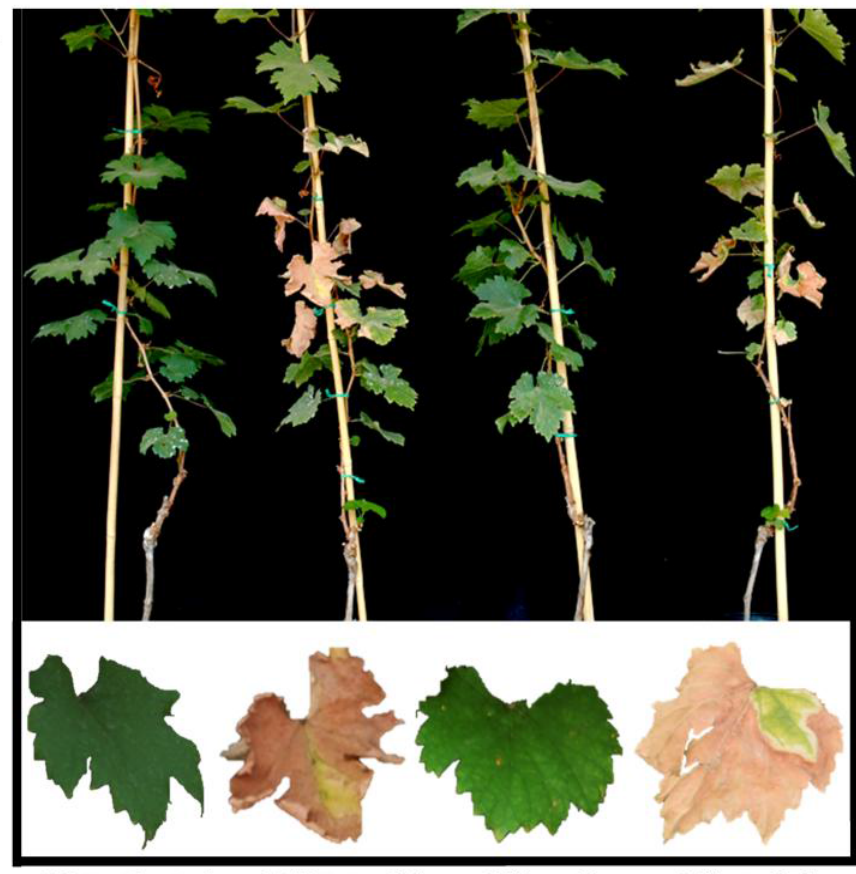

Water Control
B

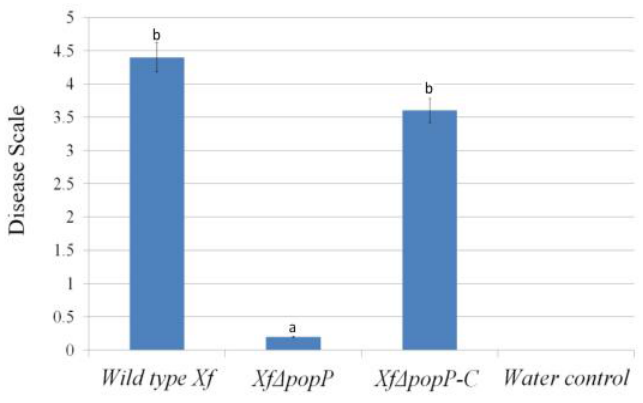

C

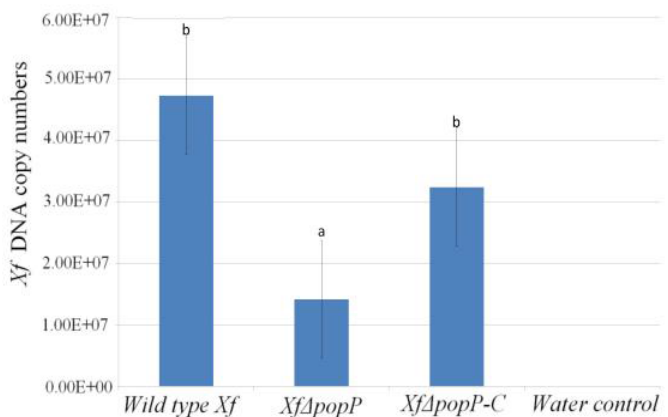

Figure 2: PD progression of Cabernet sauvignon grapevines inoculated with wild type $X$. fastidiosa, $X f \Delta p o p P$, and $X f \Delta p o p P-C$. A) Cabernet sauvignon grapevines infected with wild type $X$. fastidiosa and $X f \Delta p o p P-C$, showing typical PD symptom of the scorched leaves, whereas no PD symptom was shown on grapevines infected with $X f \triangle p o p P$. Controls are grapevines inoculated with water, which all shown no PD symptom. B) Disease severity of grapevine inoculated by all tested $X$. fastidiosa strains. Disease severity was based on a visual disease scale of 0 to 5 and was assessed 20 weeks after inoculation [28]. C) The genomic DNA copy number of wild type $X$. fastidiosa, $X f \Delta p o p P$, and $X f \Delta p o p P-C$ in infected grapevines was estimated by qPCR. Averages and standard deviations of 5 independent replicates. Error bars indicate standard deviation. Letters indicate groups assigned by significant difference test $(t$ test, $P<0.05)$.

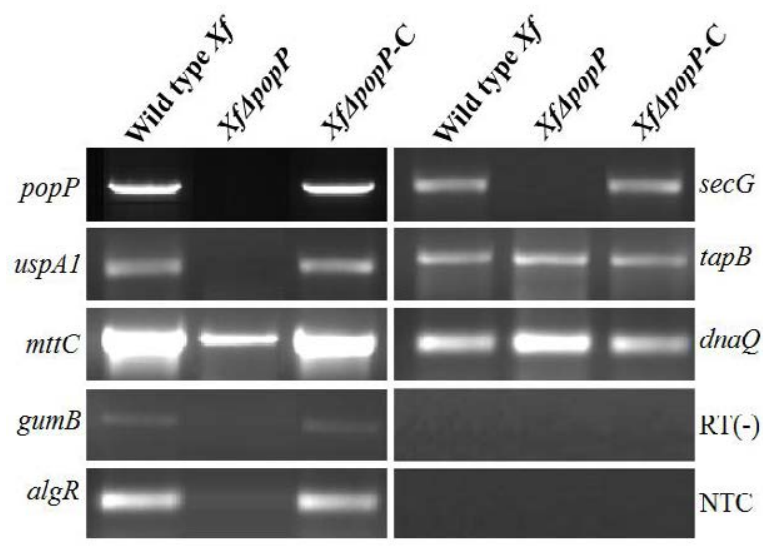

Figure 3: The detection of differential expression of virulence-related genes in wild type $X$. fastidiosa, $X f \Delta p o p P$, and $X f \Delta p o p P$-C by RT-PCR. Controls included positive control (the detectable expression of $d n a Q$ ) and negative controls [RT(-) and NTC], where RT(-) was a reaction with all components except RT reverse enzyme and NTC was a reaction with all components except RNA template. RT-PCR was conducted in three independent experiments.

secreted by type V secretion system in X. fastidiosa [55]. xatA mutant of $X$. fastidiosa shows a significant decrease in cells autoaggregation, biofilm formation, and disease symptoms on grapevines [55]. In this study type II sec-dependent secretion system sec $G$ and type V secretory pathway $m t t C$ were positively regulated by $p o p P$. The loss of $p o p P$ in
$X$. fastidiosa might affect the synthesis of type II and type V secretory pathway, resulting in the blocking of the secretions of virulence factors, and the lost the pathogenicity on grapevine.

Although TCS PhoPQ is believed to be primarily involved in phosphate metabolism as it regulates the expression of a nonspecific acid phosphatase [56], it has been experimentally verified that the PhoPQ regulates a range of genes responsible for virulence via the sensing of extracellular signal, such as nutrient and antimicrobial peptides [3,57]. Previous studies indicated the PhoPQ was necessary for $X$. oryzae pv. oryzae to be able to tolerate a change in acidic conditions ( $\mathrm{pH} 4.5$ to 6.5) after invasion of its host rice [58]. Those results imply that PhoPQ signal transduction in phytopathogenic bacteria might be induced by fluctuations $\mathrm{pH}$ in host and the presence of extracellular molecule(s). Since grape xylem is a nutritionally limited environment, subject to a fluctuating $\mathrm{pH}$ and differentially available minerals [34,59-61], $X$. fastidiosa deficient in popP may be incapable of sensing the extracellular molecule(s) or fluctuations of $\mathrm{pH}$ in host or producing the biofilm formation-related factors, secrete virulence factors, resulting in complete loss of pathogenicity on grapevine. The preliminary studies identified several heat shock proteins, translation factors, and virulence regulator likely involving interactions with PopP, implicating that PopP in X. fastidiosa might regulate a wide variety of biological processes in sensing host xylem fluctuation environmental stimuli to regulate the virulence factor of $X$. fastidiosa in hosts $[64,65]$.

While the exact molecular mechanisms by which PopP regulates in $X$. fastidiosa require further investigation, results from this study 
demonstrate that PopP plays a key role in controlling a variety of genes affecting biofilm formation and secreted virulence factors. These findings suggest that PopP is a critical component of the regulatory hierarchy governing the pathogenicity of $X$. fastidiosa in response to environmental fluctuations. These results constitute the first attempt in characterizing the pathogenicity role of popP to $\mathrm{PD}$ of grapevines, which provides new information for understanding the pathogenicity in X. fastidiosa.

\section{Acknowledgments}

Thanks to Guimei Qi for technical support. Our appreciation is also extended to Dr. Joseph Morse for comments on the manuscript. Funding for the project was supported by the United States Department of Agriculture, Agricultural Research Service. Trade names or commercial products in this publication are mentioned solely for the purpose of providing specific information and does not imply recommendation or endorsement by the United States Department of Agriculture. USDA is equal opportunity provider.

\section{References}

1. Wells JM, Raju BC, Hung HY, Weisburg WG, Mandelcopaul L, et al. (1987) Xylella fastidiosa gen. nov., sp. nov.: Gram negative, xylem limited, fastidious plant bacteria related to Xanthomonas spp. Int J Syst Bacteriol 37: 136-143.

2. Morris CE, Monier JM (2003) The ecological significance of biofilm formation by plant-associated bacteria. Annu Rev Phytopathol 41: 429-453.

3. Groisman EA (2001) The pleiotropic two-component regulatory system PhoPPhoQ. J Bacteriol 183: 1835-1842.

4. Burdman S, Shen Y, Lee SW, Xue Q, Ronald P (2004) RaxH/RaxR: a twocomponent regulatory system in Xanthomonas oryzae pv. oryzae required for AvrXa21 activity. Mol Plant Microbe Interact 17: 602-612.

5. Lee SW, Jeong KS, Han SW, Lee SE, Phee BK, et al. (2008) The Xanthomonas oryzae pv. oryzae PhoPQ two-component system is required for AvrXA21 activity, hrpG expression, and virulence. J Bacteriol 190: 2183-2197.

6. Lee SW, Han SW, Bartley LE, Ronald PC (2006) From the Academy: Colloquium review. Unique characteristics of Xanthomonas oryzae pv. oryzae AvrXa21 and implications for plant innate immunity. Proc Natl Acad Sci USA 103: $18395-18400$

7. Lee SW, Han SW, Sririyanum M, Park CJ, Seo TS, et al. (2009) A Type 1-Secreted, Sulfated Peptide triggers XA21-Mediated Innate Immunity. Science 326: 850-853.

8. Flego D, Marits R, Eriksson AR, Koiv V, Karlsson MB, et al. (2000) A twocomponent regulatory system, pehRpehS, controls endopolygalacturonase production and virulence in the plant pathogen Erwinia carotovora subsp. carotovora. Mol Plant Microbe Interact 13: 430-438.

9. Llama-Palacios A, Lopez-Solanilla E, Poza-Carrion C, Garcia-Olmedo F Rodriguez-Palenzuela P (2003) The Erwinia chrysanthemi phoP-phoQ operon plays an important role in growth at low $\mathrm{pH}$, virulence and bacterial survival in plant tissue. Mol Microbiol 49: 347-357.

10. Llama-Palacios A, López-Solanilla E, Rodríguez-Palenzuela P (2005) Role of the PhoP-PhoQ system in the virulence of Erwinia chrysanthemi strain 3937: involvement in sensitivity to plant antimicrobial peptides, survival at acid $\mathrm{Hh}$, and regulation of pectolytic enzymes. J Bacteriol 187: 2157-2162.

11. Alfano JR, Collmer A (2001) Mechanisms of bacterial pathogenesis in plants: familiar foes in a foreign kingdom. In: Groisman EA, editor. Principles of bacterial pathogensis. New York: Academic Press, pp. 180-211.

12. Scherer CA, Miller SI (2001) Molecular pathogenesis of salmonellae. In Groisman EA, editor. Principles of bacterial pathogenesis. New York: Academic Press, pp. 266-316.

13. Boyd AP, Cornelis GR (2001) Yersinia. In: Principles of bacterial pathogenesis New York: Academic Press, pp. 228-253.

14. Marceau M, Sebbane F, Ewann F, Collyn F, Lindner B, et al. (2004) The pmrF polymyxin-resistance operon of Yersinia pseudotuberculosis is upregulated by the PhoP-PhoQ two-component system but not by PmrA-PmrB, and is not required for virulence. Microbiology 150: 3947-3957.

15. Oyston PC, Dorrell N, Williams K, Li SR, Green M, et al. (2000) The response regulator PhoP is important for survival under conditions of macrophageinduced stress and virulence in Yersinia pestis. Infect Immun 68: 3419-3425.
16. Moss JE, Fisher PE, Vick B, Groisman EA, Zychlinsky A (2000) The regulatory protein PhoP controls susceptibility to the host inflammatory response in Shigella flexneri. Cell Microbiol 2: 443-452.

17. Fields PI, Groisman EA, Heffron F (1989) A Salmonella locus that controls resistance to microbicidal proteins from phagocytic cells. Science 243: 10591062.

18. Galán JE, Curtiss R (1989) Virulence and vaccine potential of phoP mutants of Salmonella typhimurium. Microb Pathog 6: 433-443.

19. Miller SI, Kukral AM, Mekalanos JJ (1989) A two-component regulatory system (phoP phoQ) controls Salmonella typhimurium virulence. Proc Natl Acad Sci USA 86: 5054-5058.

20. Gunn JS, Hohmann EL, Miller SI (1996) Transcriptional regulation of Salmonella virulence: a $\mathrm{PhoQ}$ periplasmic domain mutation results in increased net phosphotransfer to PhoP. J Bacteriol 178: 6369-6373.

21. Simpson AJ, Reinach FC, Arruda P, Abreu FA, Acencio M, et al. (2000) The genome sequence of the plant pathogen Xylella fastidiosa. The Xylella fastidiosa Consortium of the Organization for Nucleotide Sequencing and Analysis. Nature 406: 151-159.

22. Shi XY, Dumenyo CK, Hernandez-Martinez R, Azad H, Cooksey DA (2007) Characterization of regulatory pathways in Xylella fastidiosa: genes and phenotypes controlled by algU. Appl Environ Microbiol 73: 6748-6756.

23. Matsumoto A, Young GM, Igo MM (2009) Chromosome-based genetic complementation system for Xylella fastidiosa. Appl Environ Microbiol 75 1679-1687.

24. Kustu S, Santero E, Keener J, Popham D, Weiss D (1989) Expression of sigma 54 (ntrA)-dependent genes is probably united by a common mechanism. Microbiol Rev 53: 367-376.

25. Chuang SE, Daniels DL, Blattner FR (1993) Global regulation of gene expression in Escherichia coli. J Bacteriol 175: 2026-2036.

26. Shi XY, Dumenyo CK, Hernandez-Martinez R, Azad H, Cooksey DA (2009) Characterization of regulatory pathways in Xylella fastidiosa: genes and phenotypes controlled by gacA. Appl Environ Microbiol 75: 2275-2283.

27. Lin H, Doddapaneni H, Takahashi Y, Walker MA (2007) Comparative analysis of ESTs involved in grape responses to Xylella fastidiosa infection. BMC Plant Biol 7: 8.

28. Guilhabert MR, Kirkpatrick BC (2005) Identification of Xylella fastidiosa antivirulence genes: hemagglutinin adhesins contribute a biofilm maturation to $\mathrm{X}$. fastidios and colonization and attenuate virulence. Mol Plant Microbe Interact 18: 856-868.

29. Francis M, Lin H, Rosa J, Doddapaneni H, Civerolo EL (2006) Genome-based PCR primers for specific and sensitive detection and quantification of Xylella fastidiosa. Eur J Plant Pathol 115: 203-213.

30. Minsavage GV, Thompson CM, Hopkins DL, Leite RMVBC, Stall RE (1994) Development of a polymerase chain reaction protocol for detection of Xylella fastidiosa in plant tissue. Phytopathology 84: 456-461.

31. Burdman S, Jurkevitch E, Soria-Díaz ME, Serrano AM, Okon Y (2000) Extracellular polysaccharide composition of Azospirillum brasilense and its relation with cell aggregation. FEMS Microbiol Lett 189: 259-264.

32. Leite B, Andersen PC, Ishida ML (2004) Colony aggregation and biofilm formation in xylem chemistry-based media for Xylella fastidiosa. FEMS Microbiol Lett 230: 283-290.

33. Van Sluys MA, de Oliveira MC, Monteiro-Vitorello CB, Miyaki CY, Furlan LR et al. (2003) Comparative analyses of the complete genome sequences of Pierce's disease and citrus variegated chlorosis strains of Xylella fastidiosa. $J$ Bacteriol 185: 1018-1026.

34. Bi JL, Dumenyo CK, Hernandez-Martinez R, Cooksey DA, Toscano NC (2007) Effect of host plant Xylem fluid on growth, aggregation, and attachment of Xylella fastidiosa. J Chem Ecol 33: 493-500.

35. Shi X, Bi J, Morse JG, Toscano NC, Cooksey DA (2010) Differential expression of genes of Xylella fastidiosa in xylem fluid of citrus and grapevine. FEMS Microbiol Lett 304: 82-88.

36. Fritschi FB, Lin H., Walker MA (2007) Xylella fastidiosa Population Dynamics in Grapevine Genotypes Differing in Susceptibility to Pierce's Disease. Am J Enol Vitic 3: 326-332. 
37. Pierce BK, Kirkpatrick BC (2015) The PhoP/Q two-component regulatory system is essential for Xylella fastidiosa survival in Vitis vinifera grapevines. Phys Mol Plant Pathol 89: 55-61.

38. Osiro D, Colnago LA, Otoboni AM, Lemos EG, de Souza AA, et al. (2004) A kinetic model for Xylella fastidiosa adhesion, biofilm formation, and virulence. FEMS Microbiol Lett 236: 313-318.

39. Purcell AH, Hopkins DL (1996) Fastidious xylem-limited bacterial plant pathogens. Annu Rev Phytopathol 34: 131-151.

40. Kang Y, Liu H, Genin S, Schell MA, Denny TP (2002) Ralstonia solanacearum requires type 4 pili to adhere to multiple surfaces and for natural transformation and virulence. Mol Microbiol 46: 427-437.

41. Ojanen-Reuhs T, Kalkkinen N, Westerlund-Wikström B, van Doorn J, Haahtela $\mathrm{K}$, et al. (1997) Characterization of the fimA gene encoding bundle-forming fimbriae of the plant pathogen Xanthomonas campestris pv. vesicatoria. J Bacteriol 179: 1280-1290.

42. Romantschuk M, Bamford DH (1986) The causal agent of halo blight in bean Pseudomonas syringae pv. phaseolicola, attaches to stomata via its pili. Microb Pathog 1: 139-148.

43. van Doorn J, Boonekamp PM, Oudega B (1994) Partial characterization of fimbriae of Xanthomonas campestris pv. hyacinthi. Mol Plant Microbe Interact 7: 334-344.

44. Souza LC, Wulff NA, Gaurivaud P, Mariano AG, Virgílio AC, et al. (2006) Disruption of Xylella fastidiosa CVC gumB and gumF genes affects biofilm formation without a detectable influence on exopolysaccharide production. FEMS Microbiol Lett 257: 236-242.

45. Coyne MJ Jr, Russell KS, Coyle CL, Goldberg JB (1994) The Pseudomonas aeruginosa algC gene encodes phosphoglucomutase, required for the synthesis of a complete lipopolysaccharide core. J Bacteriol 176: 3500-3507.

46. de Souza AA, Takita MA, Pereira EO, Coletta-Filho HD, Machado MA (2005) Expression of pathogenicity-related genes of Xylella fastidiosa in vitro and in planta. Curr Microbiol 50: 223-228.

47. Martin DW, Schurr MJ, Yu H, Deretic V (1994) Analysis of promoters controlled by the putative sigma factor AlgU regulating conversion to mucoidy in Pseudomonas aeruginosa: relationship to sigma $E$ and stress response. $J$ Bacteriol 176: 6688-6696.

48. Caserta R, Takita MA, Targon ML, Rosselli-Murai LK, de Souza AP, et al. (2010) Expression of Xylella fastidiosa fimbrial and afimbrial proteins during biofilm formation. Appl Environ Microbiol 76: 4250-4259.

49. Chatterjee S, Wistrom C, Lindow SE (2008) A cell-cell signaling sensor is required for virulence and insect transmission of Xylella fastidiosa. Proc Nat Acad Sci U S A 105: 2670-2675.

50. Dautin N, Bernstein HD (2007) Protein secretion in gram-negative bacteria via the autotransporter pathway. Annu Rev Microbiol 61: 89-112.
51. Henderson IR, Navarro-Garcia F, Desvaux M, Fernandez RC, Ala'Aldeen D (2004) Type V protein secretion pathway: the autotransporter story. Microbiol Mol Biol Rev 68: 692-744.

52. Bruening G, Civerolo EL, Lee Y, Buzayan JM, Feldstein PA, et al. (2005) A major outer membrane protein of Xylella fastidiosa induces chlorosis in Chenopodium quinoa. Phytopathology 95: S14.

53. Nandi B, Nandy RK, Mukhopadhyay S, Nair GB, Shimada T, et al. (2000) Rapid method for species-specific identification of Vibrio cholerae using primers targeted to the gene of outer membrane protein OmpW. J Clin Microbiol 38 : 4145-4151.

54. Pugsley AP (1993) The complete general secretory pathway in gram-negative bacteria. Microbiol Rev 57: 50-108.

55. Matsumoto A, Huston SL, Killiny N, Igo MM (2012) XatA, an AT-1 autotransporter important for the virulence of Xylella fastidiosa Temecula1. Microbiologyopen 1: $33-45$.

56. Kier LD, Weppelman RM, Ames BN (1979) Regulation of nonspecific acid phosphatase in Salmonella: phoN and phoP genes. J Bacteriol 138: 155-161.

57. García Véscovi E, Soncini FC, Groisman EA (1996) Mg2+ as an extracellular signal: environmental regulation of Salmonella virulence. Cell 84: 165-174.

58. Grignon C, Sentenac $\mathrm{H}$ (1991) pH and ionic conditions in the apoplast. Annu Rev Plant Phys 42: 103-128.

59. Alves G, Ameglio T, Guilliot A, Fleurat-Lessard P, Lacointe A, et al. (2004) Winter variation in xylem sap $\mathrm{pH}$ of walnut trees: involvement of plasma membrane H+-ATPase of vessel-associated cells. Tree Physiol 24: 99-105.

60. Andersen PC, Brodbeck BV, Oden S, Shriner A, Leite B (2007) Influence of xylem fluid chemistry on planktonic growth, biofilm formation and aggregation of Xylella fastidiosa. FEMS Microbiol Lett 274: 210-217.

61. Basha SM, Mazhar H, Vasanthaiah HK (2010) Proteomics approach to identify unique xylem sap proteins in Pierce's disease-tolerant Vitis species. Appl Biochem Biotechnol 160: 932-944.

62. Kovach ME, Phillips RW, Elzer PH, Roop RM 2nd, Peterson KM (1994) pBBR1MCS: a broad-host-range cloning vector. Biotechniques 16: 800-802.

63. Davis MJ, French WJ, Schaad NW (1981) Axenic culture of the bacteria associated with phony peach disease of peach and plum leaf scald. Curr Microbiol 6: 309-314

64. Krivanek AF, Famula TR, Tenscher A, Walker MA (2005) Inheritance of resistance to Xylella fastidiosa within a Vitis rupestris $\mathrm{x}$ Vitis arizonica hybrid population. Theor Appl Genet 111: 110-119.

65. Krivanek AF, Stevenson JF, Walker MA (2005) Development and Comparison of Symptom Indices for Quantifying Grapevine Resistance to Pierce's Disease. Phytopathology 95: 36-43. 